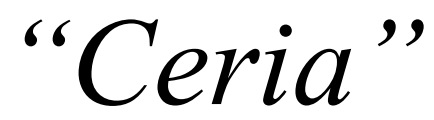

Jurnal Program Studi Pendidikan Anak Usia Dini

ISSN 2301-9905

Volume 8, No. 1, Juli 2018

Fakultas Keguruan dan Ilmu Pendidikan- Universitas Muhammadiyah Tangerang

\title{
Penerapan Metode Montessori Untuk Anak Down Syndrome
}

\author{
Alfisyhr Kirana ${ }^{1}$, Nurul Fitria Kumala Dewi ${ }^{2}$ \\ 1,2Program Studi Pendidikan Guru Pendidikan Anak Usia Dini \\ Fakultas Keguruan dan Ilmu Pendidikan Universitas Muhammadiyah Tangerang \\ e-mail: ${ }^{1}$ alviskirana@gmail.com, ${ }^{2}$ nurulfitriakd@gmail.com
}

\begin{abstract}
Abstrak
Setiap anak memiliki hak dan kewajiban untuk berpendidikan, hak untuk tumbuh dan berkembang terlebih di usia keemasan anak atau yang biasa disebut dengan Golden Age, memiliki kebebasan untuk tumbuh dan berkembang. Tidak ada yang membedakan antara anak normal dengan anak dengan keterbelakangan mental seperti down syndrome. Kurangnya pengetahuan orangtua terkait memberikan pendidikan kepada anak down syndrome mereka, menjadikan penelitian ini sangat dibutuhkan, berfokus pada penanganan anak down syndrome dengan metode Montessori yaitu memberikan kebebasan dan kesempatan-kesempatan interaksi yang dilakukan oleh anak down syndrome dengan cara yang edukatif. Melalui metode penelitian kualitatif studi kasus, ditemukanah bahwa metode Montessori melalui kegiatan-kegiatannya, memberikan prospek positif bagi pertumbuhan dan perkembangan anak Down Syndrome.
\end{abstract}

Kata kunci : Metode Montessori, Anak Down Syndrome

\section{Pengantar}

Setiap anak normal maupun anak disabilitas memiliki hak dan kewajiban untuk mendapatkan pendidikan, hak untuk tumbuh dan berkembang terlebih di usia keemasan anak atau yang biasa disebut dengan Golden Age, di masa keemasan inilah setiap stimulasi yang diterima oleh anak akan menjadi pondasi pertumbuhan dan perkembangan anak kelak, sehingga dapat mencapai tingkat yang diinginkannya bahkan tidak terbatas. Perbedaan penanganan terhadap anak disabilitas tentu saja dibutuhkan, menyatukan antara penanganan medis dan pemberian pedidikan khusus. 
"Ceria"

Jurnal Program Studi Pendidikan Anak Usia Dini

Berdasarkan prinsip Montessori bahwa defisiensi mental membutuhkan satu jenis pendidikan khusus yang dijalankan menggunakan bahan-bahan dan alat-alat pembelajaran, dan tidak hanya pada penganan medis saja (Lazuardi, 2013, h. 12).

Pemberian penanganan kepada anak dengan disabilitas (dan dalam penelitian ini Down Syndrome) bertujuan untuk menggali potensi yang dimiliki setiap anak, menstimulasi berbagai kegiatan untuk mencapai tugas perkembangan, terutama akan kemandirian hidup. Bekal kemandirian hidup menjadi pokok penting untuk kehidupan anak kelak, kemampuan dasar yang akan membentuk kepribadian anak, serta penunjang perkembangan kognitif dan perkembagan lainnya. Sehingga dalam kasus penelitian ini, orangtua mengutamakan stimulasi anak untuk menggali kemampuan-kemampuannya, dan mengembangkannya secara optimal.

Terdapat berbagai cara untuk memberikan stimulasi pada anak untuk merangsang perkembangan dan pertumbuhannya, antara lain adalah dengan memberikan kegiatan yang bersumber dari lingkungan sekitar, dan dilakukan bersama orang-orang di sekitar anak. Orangtua atau pendidik memanfaatkan lingkungan sebagai media eksplorasi anak, memfasilitasi serta mendampingi kegiatan mereka. Lingkungan yang dimanfaatkan dengan baik, akan menjadi media penting bagi perkembangan anak, kepercayaan diri anak juga akan tumbuh dan dia akan terus mencoba dan bereksplorasi.

Berdasarkan observasi yang dilakukan peneliti pada satu anak down syndrome usia 4 tahun, bahwa perkembangan anak tersebut telah banyak sekali berkembang, menembus tugas-tugas perkembangan mencapai bekal kemandirian hidup, hingga jika boleh dikatakan bahwa anak tersebut melebihi anak sesamanya dan seusianya. Melihat pada skala perkembangan anak Down Syndrome, bermula dari usia anak tersebut kurang lebih 3 tahun, sudah banyak sekali poin-poin tugas perkembangan yang sudah berhasil dilewati oleh anak, jauh berbeda pada usia sebelumnya. Perkembangan tersebut terus meningkat di usia anak selanjutnya, sehingga semakin banyak kemampuan yang terlihat dan potensi-potensi yang dimilikinya. 
"Ceria"

Jurnal Program Studi Pendidikan Anak Usia Dini

Metode Montessori menjadi salah satu bentuk stimulasi yang diberikan oleh orangtua. Metode Montessori merupakan suatu metode yang didasarkan pada konsep tentang ilmu pengetahuan, pada pengamatan-pengamatannya terhadap anak-anak, dan pada riset-riset yang luas dalam bidang antropologi, psikologi dan pedagogi. Metode Montessori memiliki dua cakupan penting dalam proses pendidikan ; anak secara individu dan lingkungan (Lazuardi, 2013, h. 71-72). Tidak jauh berbeda, Kusumo (2016, h. 9) menyebutkan bahwa metode Montessori adalah sebuah gaya hidup yang dimulai dari rumah, saat anak diberi kesempatan berkembang dan mengeksplorai setiap sudut rumah dengan aman atau child friendly. Sementara Walls $(2017$, h. 5) mengungkapkan bahwa metode Montessori didasarkan pada rasa keingintahuan anak yang tumbuh secara alamiah, dan keinginan mereka untuk belajar, guru memberikan bahan dan lingkungan anak untuk membantu perkembangannya, dan siap memberikan respon untuk memberikan bantuan kepada anak.

Orangtua atau pendidik dalam penerapan metode Montessori ini, menjadi fasilitator agar setiap stimulasi kegiatannya sesuai dengan kebutuhan perkembangan anak. Kegiatan-kegiatan yang diberikan kepada anak (dalam penelitian ini) lebih banyak tentang kegiatan sehari-sehari, seperti cara memegang sendok serta alat makan, merapikan mainan, dan kemampuan untuk membersihkan diri.

Dengan demikian penerapan metode Montessori dapat menjadi stimulasi efekif bagi anak Down Syndrome, melalui learning by doing menjadikan anak lebih merasakan pengalaman nyata bagaimana semua potensinya bertahahap berkembang memenuhi tugas-tugas perkembangannya.

\section{Metode}

Metode penelitian yang dilakukan dalam penelitian ini adalah Penelitian Kualitatif Studi Kasus dengan jenis tunggal, dengan subjek penelitian yaitu anak Down Syndrome usia 4 tahun. Penelitian kualitatif dilakukan dengan maksud untuk memahami fenomena tentang apa yang dialami oleh subjek penelitian, dan dalam hal 
"Ceria"

Jurnal Program Studi Pendidikan Anak Usia Dini

ini dilakukan dengan memandang anak secara utuh sebagai pribadi yang berinteraksi dengan lingkungannya. Adapun bentuk penelitian kualitatif yang dilakukan adalah studi kasus, yaitu penelitian yang dilakukan untuk mengetahui lebih mendalam dan terperinci tentang suatu permasalahan atau fenomenan yang hendak diteliti (Yin dan Tohirin, 2012, h.20).

Tahapan yang dilakukan Peneliti yaitu : Pertama, melakukan observasi pra-penelitian 1 dan 2, peneliti mengamati subjek sebelum penelitian ini secara resmi dilakukan. Kedua, taahapan observasi, peneliti melanjutkan pengamatan dengan melihat kondisi dan perkembangan anak. Ketiga, tahap observasi lanjutan yang bertujuan mencari tahu lebih dalam apa yang dilakukan orangtua subjek sehingga anak semakin meningkat perkembangannya. Di setiap pengamatan yang peneliti lakukan, peneliti juga melakukan observasi vokal yaitu mewawancarai orangtua subjek, untuk lebih dekat kepada hasil dari muatan sumber penelitian.

Analisa data yang Peneliti lakukan melalui dua acara, yaitu langsung di lapangan dan setelah data terkumpul. Peneliti melakukan pemilihan data, merangkai data, dan kemudian menyimpulkan keterkaitannya.

\section{Hasil dan Pembahasan}

Peningkatan perkembangan anak terlihat selama penerapan metode Montessori, peningkatan tersebut dibuktikan dengan melihat skala perkembangan anak Down Syndrome di setiap usianya. Membandingkan dengan usia tahun pertama yaitu saat sebelum penerapan metode Montessori, tidak ada perkembangan apapun yang terjadi pada anak. Selanjutnya bertambah usia sekitar 2 tahun, saat orangtua mulai mengenal dan menerapkan metode Montessori, satu demi satu tugas perkembangan di usia sebelumnya dapat terlewati. Selanjutnya memasuki usia tahun ketiga, semakin banyak poin tugas perkembangan yang tertinggal dapat dikejar, dan tugas perkembangan di usianya juga terlaksana dengan baik. Sampai memasuki tahun ke-empat usia anak, 
"Ceria"

Jurnal Program Studi Pendidikan Anak Usia Dini

penerapan metode Montessori semakin mudah dilakukan hingga anak terus meningkatkan potensi dirinya.

Pemberian kegiatan berdasarkan metode Montessori tidak serta merta dapat diterima oleh anak, akan tetapi ada tahapan-tahapan yang terjadi selama proses tersebut, berbagai ekspresi penolakan, pengacuhan hingga ketertarikan muncul di setiap kegiatan. Tahapan atau proses yang dilalui menjadi stimulasi dan pengalaman eksplorasi yang sangat berguna bagi anak, karena melalui proses-proses tersebut anak semakin banyak melalui pembelajaran perkembangan, meraih keberhasilan tugas-tugas perkembangannya sendiri.

\section{Kesimpulan}

Berdasarkan hasil penelitian yang dilakukan melalui beberapa tahapan, bahwa penerapan metode Montessori memberikan kotribusi positif sebagai stimulasi perkembangan anak Down Syndrome. Metode Montessori memberikan pengaruh yang besar terhadap pengalaman eksplorasi anak di lingkungannya dan bersama orang-orang yang juga di dalam lingkungannya, sehingga anak Down Syndrome mendapatkan kepercayaan untuk tumbuh dan berkembang bertahap. Keberhasilan penerapan metode Montessori tentu saja dilihat melalui kejadian saat ini, dan membandingkannya dengan usia sebeumnya di tahun pertama dan kedua, tidak adanya poin perkembangan yang berhasil dilalui oleh anak di masa sebelum penerapan, dan semakin banyaknya poin-poin perkembangan yang terlewati di masa setelah penerapan metode Montessori.

Berdasarkan kesimpulan di atas, ada beberapa hal penting yang dapat ditindak lanjuti yaitu : Mengingat bahwa penerapan metode Montessori untuk anak Down Syndrome masih sangat awam di lingkungan masyarakat, dan dalam penelitian ini dilakukan secara perorangan, maka kajian dalam penelitian ini masih jauh dari hasil yang sempurna. 
"Ceria"

Jurnal Program Studi Pendidikan Anak Usia Dini

Saran yang diajukan penulis kepada orangtua atau instansi yang ingin menerapkan, untuk lebih memperbanyak wawasan tentang ilmu terkait, dan bergabung dengan komunitas Montessori, salah satunya Indonesia Montessori Club.

\section{Daftar Acuan}

Kusumo, E. L. (2016). Montessori di Rumah : 55 kegiatan practical life. Jakarta: Erlangga.

Montessori, M. (2013). Metode Montessori. (G. L. Gutek, Ed., \& A. L. Lazuardi, Trans.) Yogyakarta: Pustaka Pelajar.

Tohirin. (2012). Metode Penelitian Kualitatif dalam Pendidikan dan Bimbingan Konseling. Jakarta : Rajawali Press.

Walls, C. H. (2017). Montessori in A Nutshell . New York: Waterpark Books. 